\title{
Effect of Exogenously Administered Methyl Farnesoate and 20-OH Ecdysone on Polypeptide Profile of Vitellogenin and Vitellin in the Freshwater Crab Travancoriana schirnerae
}

\section{Aswani Ayanath, Sudha Devi Arath Raghavan*}

\author{
Department of Zoology, Mary Matha Arts E Science College, Wayanad, Kerala 670 645, India.
}

\begin{abstract}
This study evaluated the effects of exogenously administered methyl farnesoate (MF) and 20-OH ecdysone $(20 \mathrm{E})$ on polypeptide profile of circulating vitellogenin $(\mathrm{Vg})$ and ovarian vitellin $(\mathrm{Vn})$ in the edible freshwater crab Travancoriana schirnerae by sodium dodecyl sulphate-polyacrylamide gel electrophoresis. The results indicated that the polypeptide profiles of yolk proteins in the hemolymph and ovary of control and experimental females varied with the stage of development of the ovary. Our observations also revealed that both $\mathrm{MF}$ and $20 \mathrm{E}$ administration was able to induce the production of $\mathrm{Vg}$ and $\mathrm{Vn}$ during the avitellogenic and previtellogenic phases manifested by the presence of $\mathrm{Vg}$ and $\mathrm{Vn}$ polypeptide subunits in the electropherograms of experimentals over the controls. Moreover, the electropherograms of MF and $20 \mathrm{E}$ crabs during the vitellogenic phase displayed more number of $\mathrm{Vg}$ and $\mathrm{Vn}$ subunits with increased staining intensity and thickness compared to the control crabs. It was concluded that though both $\mathrm{MF}$ and $20 \mathrm{E}$ were able to induce or enhance the production of $\mathrm{Vg}$ and $\mathrm{Vn}$ during the avitellogenic, previtellogenic and vitellogenic phases, the effects were far more pronounced in MF injected females than the $20 \mathrm{E}$ injected crabs.
\end{abstract}

Keywords: Hemolymph, Ovary, SDS-PAGE analysis, Vitellin, Vitellogenin

Editor | Muhammad Nauman Zahid, Quality Operations Laboratory, University of Veterinary and Animal Sciences, Lahore, Pakistan.

Received | June 22, 2020 Accepted | July 15, 2020; Published | August 10, 2020

*Correspondence | Sudha Devi Arath Raghavan, Department of Zoology, Mary Matha Arts \& Science College, Wayanad, Kerala 670 645, India; Email: arsudhadevi@gmail.com

Citation | Ayanath A, Raghavan SDA (2020). Effect of exogenously administered methyl farnesoate and 20-oh ecdysone on polypeptide profile of vitellogenin and vitellin in the freshwater crab Travancoriana schirnerae S. Asian J. Life Sci. 8(2): 55-63.

DOI | http://dx.doi.org/10.17582/journal.sajls/2020/8.2.55.63

ISSN | 2311-0589

Copyright $\odot 2020$ Ayanath and Raghavan. This is an open access article distributed under the Creative Commons Attribution License, which permits unrestricted use, distribution, and reproduction in any medium, provided the original work is properly cited.

\section{INTRODUCTION}

G rowth and differentiation of the oocyte in crustaceans can be divided into three phases: avitellogenic, previtellogenic and vitellogenic. The latter phase was characterized by the synthesis of the yolk protein, vitellogenin $(\mathrm{Vg})$ in the hepatopancreas, its subsequent release to the hemolymph and incorporation by the developing oocytes (see reviews by Charniaux-Cotton, 1985; Meusy and Payen, 1988). The yolk protein precursor, $\mathrm{Vg}$, was further modified with the addition of carbohydrate and lipid moieties to form vitellin $(\mathrm{Vn})$ in which form it was stored in the oocytes for nourishing the embryo (see review by Meusy and Payen, 1988; Pateraki and Stratakis, 1997). In crustaceans, the synthesis of yolk may be endogenous (within the ovary) or exogenous (in the hepatopancreas) or both (see reviews by Meusy, 1980 and Tsukimura, 2001; Avarre et al., 2003; Auttarat et al., 2006). Endogenous vitellogenesis encompassed the formation of proteinaceous and glycoproteinaceous yolk which appeared as yolk globules in the oocytes whereas exogenous vitellogenesis involved the synthesis of lipid yolk in the hepatopancreas and its sequestration by the ovary (see review by Meusy, 1980).

The process of vitellogenesis was controlled by both neuroendocrine and non-neuroendocrine factors (Charmantier et al., 1997; Van Herp and Soyez, 1997). Neuroendocrine factors include the neurohormones: the gonad stimulating hormone (GSH), also called the vitellogenesis stimulating hormone (VSH) originating from the brain and thoracic 
ganglion and the gonad inhibiting hormone (GIH), also called the vitellogenesis inhibiting hormone (VIH) derived from the $\mathrm{X}$-organ-sinus gland (XO-SG) complex of the eyestalk. The non-neuroendocrine secretions include the terpenoid hormone methyl farnesoate (MF) released from the mandibular organ and the ecdysteroids secreted by the $\mathrm{Y}$ organ. Many authors suggested the presence of a $\mathrm{Vg}$ stimulating ovarian hormone (VSOH) in follicle cells surrounding the vitellogenic oocytes (Picaud and Souty, 1980; Zerbib and Meusy, 1983).

In addition to the important roles played in the regulation of moulting, larval development and morphogenesis (Abdu et al., 1998; Reddy et al., 2004), MF, the crustacean equivalent of the juvenile hormone III of insects, functioned as a gonadotropin. The gonadotropic effect of MF and farnesoic acid (precursor to $\mathrm{MF}$ ) has been reported in a number of crustaceans (Rodriguez et al., 2002; Mak et al., 2005; Tiu et al., 2006; Balasubramanian et al., 2010; Reddy and Reddy, 2015; Hemalatha et al., 2016; Sudha Devi and Aswani, 2018; Muhd-Farouk et al., 2019). In vitro studies by Otsu (1963) reported that MF promoted the development of oocyte and $\mathrm{Vg}$ messenger in the hepatopancreas and ovary. Exogenously administered MF enhanced the Vg titer in the hemolymph of eyestalk ablated Libinia emarginata (Vogel and Borst, 1989), Penaeus indicus (Nagaraju et al., 2002) and Macrobrachium malcolmsonii (Nagaraju et al., 2003). Medesani et al. (2012) specified the direct effect of MF on synthesis of ovarian proteins in the crayfish Cherax quadricarinatus.

Besides the prime function of controlling moulting and growth, crustacean ecdysteroids played crucial roles in reproduction (Chang et al., 2001; See reviews by Subramoniam, 2000, 2017). Several authors described the ecdysteroid induced stimulation of vitellogenesis, i.e. synthesis, release and transport of $\mathrm{Vg}$ to the ovary (Kanazawa and Teshima, 1971; Chaix and De Reggi, 1982; Souty et al., 1982). In the amphipod Orchestia gammarella, high 20$\mathrm{OH}$ ecdysterone (20E) concentration was vital for Vg production in the hepatopancreas (Blanchet-Tournier, 1982). Steel and Vafopoulou (1998) stated that the hemolymph $\mathrm{Vg}$ titer paralleled ecdysteroid titer during vitellogenesis in isopods and amphipods. Protein synthesis in the ovary and integuementary tissues was heightened following $20 \mathrm{E}$ administration in the sand crab Emerita asiatica (Gunamalai et al., 2004). Tiu et al. (2006) described the relationship between the hemolymph ecdysteroid titer and $\mathrm{Vg}$ gene expression in the ovary and hepatopancreas of $P$. monodon.

Travancoriana schirnerae is an edible freshwater crab commonly distributed in the wetlands of Wayanad, Kerala. The ovary consumed by the native tribes during the breeding season, is a very good source of inexpensive, high quality protein. Though ample literature is available regarding the role of MF and ecdysteroids on yolk protein synthesis in marine decapods, literature is meager on freshwater brachyurans and a detailed study in this regard is required to establish this. The current study evaluated the effects of exogenously administered $\mathrm{MF}$ and $20 \mathrm{E}$ on levels of circulating $\mathrm{Vg}$ and ovarian $\mathrm{Vn}$ profile during different stages of development of the ovary in the freshwater crab $T$. schirnerae, which is an important step in understanding the process of vitellogenesis of the species under study.

\section{MATERIALS AND METHODS}

Adult intermoult crabs (CW: $3.5-4.5 \mathrm{~cm}$; weight: $35-40$ $\mathrm{g})$ in various oogenic stages $(\mathrm{n}=45)$ were collected over a period of one year from January 2019 to December 2019 from the paddy fields of Ondayangadi, Wayanad, Kerala $\left(11^{\circ} 49^{\prime} 20.3^{\prime \prime} \mathrm{N}\right.$ and $\left.76^{\circ} 01^{\prime} 47.1^{\prime \prime} \mathrm{E}\right)$. The specimens were transported to the laboratory alive, kept in well-aerated circular plastic basins (diameter $46 \mathrm{~cm}$, depth $20 \mathrm{~cm}$ ) $(5$ individuals per basin) containing well water for acclimatization. The crabs were fed ad libitum with boiled egg, pieces of cooked beef liver and decaying aquatic vegetation, daily once during the acclimatization (2-3 days) and experimental period. The water in the basins were changed daily, one hour after feeding. The temperature and photoperiod conditions were maintained $\left(25 \pm 3^{\circ} \mathrm{C}\right.$ and $\left.12 \mathrm{~L}: 12 \mathrm{D}\right)$ through the experimental period.

\section{Experimental Design}

The individuals were distributed into three groups $(n=15)$. The carapace width (body size) and body weights (Shimadzu electronic top loading balance, sensitivity $0.001 \mathrm{~g}$ ) were recorded for all the specimens. Group I comprised of intact crabs without treatment while Groups II and III were given injections of MF (trans, trans MF; Echelon Biosciences, Salt Lake City, USA) and 20E (Sigma Chemicals, USA) at doses of 25 and $40 \mathrm{ng} / \mathrm{g}$ body weights, respectively. The injections were given weekly once, on the first, seventh, fourteenth and twenty first day of the experiment through the arthrodial membrane of the coxal segment of the third walking leg. Both controls and experimentals were sacrificed one week after the last injection (on day 28). For analysis of the yolk proteins, the hemolymph and ovarian samples collected from the control and experimental groups were subjected to sodium dodecyl sulphate-polyacrylamide gel electrophoresis (SDS-PAGE).

\section{Preparation of Hemolymph Sample for Sds-}

\section{Page Analysis}

The hemolymph samples (approximately $500 \mu \mathrm{L}$ each) collected separately from females in various oogenic stages (avitellogenic, early previtellogenic, late previtellogenic, early, middle and late vitellogenic stages ( $\mathrm{n}=5$ each) by puncturing the walking legs were placed in sterile centri- 
fuge tubes. The samples in each oogenic stage were pooled and $100 \mu \mathrm{L}$ of the sample was mixed with Trichloroaceticacid (10\%) and centrifuged (REMI, India) at 2000 rpm for $10 \mathrm{~min}$. The pellets were collected and washed in distilled water and homogenized in SDS sample buffer containing $10 \%$ SDS, glycerol, $\beta$-mercapto-ethanol, $0.1 \%$ bromophenol blue and $0.5 \mathrm{M}$ Tris- $\mathrm{HCl}(\mathrm{pH}$ 6.8), using an ice-cold homogenizer. The homogenate was denatured in a boiling water bath for 5 minutes and then cooled immediately. The supernatant obtained after centrifugation at $2000 \mathrm{rpm}$ for $30 \mathrm{~min}$ was used for SDS-PAGE analysis.

\section{Preparation of Ovarian Homogenates}

Pieces of ovary from various oogenic stages $(n=5 ; 10 \mathrm{mg}$ each) were homogenized in extraction buffer containing $10 \%$ SDS, glycerol, $\beta$-mercapto-ethanol, $0.1 \%$ bromophenol blue and $0.5 \mathrm{M}$ Tris- $\mathrm{HCl}(\mathrm{pH} 6.8)$ with a mortar and pestle. The homogenates were denatured in boiling water bath for 5 minutes and cooled immediately. The samples were centrifuged at $2000 \mathrm{rpm}$ for 30 minutes. After centrifugation, a lipid cap was formed at the top of the centrifuge tube and pellets of cell debris deposited at the bottom. The aqueous supernatant was carefully transferred with a micropipette to another fresh tube and used as sample for SDS-PAGE analysis.

\section{ELECTROPHORESIS}

The SDS-PAGE was performed according to the method of Laemmli (1970) using a 7\% gradient slab gel. The samples and standard $(10 \mu \mathrm{L}$ each) were loaded on a $4 \%$ stacking gel. The separation of polypeptide fractions was conducted with an electrophoresis buffer containing $25 \mathrm{mM}$ Tris, $200 \mathrm{mM}$ glycine and $0.1 \% \mathrm{SDS}, \mathrm{pH} 8.3$, in a vertical slab gel electrophoresis unit $(16 \times 14 \mathrm{~cm}$ gel, Biotech, India). The initial voltage was maintained at $60 \mathrm{~V}$ till the tracking dye, bromophenol blue, touched the lowermost portion of the stacking gel and then increased to $100 \mathrm{~V}$. The electrophoretic run was continued for 5 hours, until the dye front reached the bottom line of the resolving gel.

Once the electrophoretic run completed, the gels were transferred to $50 \%$ methanol in order to fix the polypeptide bands and stained with $0.1 \%$ Coomassie Brilliant Blue R-250 (50\% distilled water, $40 \%$ methanol and $10 \%$ acetic acid mixture) for 1 hour at room temperature. The gel was then transferred to the destaining solution (distilled water, methanol and acetic acid mixture in 50:40:10 ratio) in which it was stored. After destaining, the gels were photographed using a Sony HX $400 \mathrm{~V}$ digital camera. The molecular weights of polypeptide subunits were determined by comparing their relative mobility in SDS-PAGE with those of the standard protein markers (New England BioLabs, UK) of known molecular weights.

\section{RESULTS}

Travancoriana schirnerae was an annual breeder, accommodating a single ovarian cycle. The annual ovarian cycle was divided into 3 phases: avitellogenic (April-May), previtellogenic (June-September) and vitellogenic (October-March). The vitellogenic phase was further divided into early (October), middle (November-January) and late (February-March) stages. Our observations revealed that the electrophoretic profiles of yolk proteins in the hemolymph and ovary of control and experimental females varied with the stage of development of the ovary (Figures 1-2).

\section{Effect of Mf and 20E Administration on Yolk Protein Concentration in Avitellogenic and Previtellogenic Phases}

The electropherograms of the hemolymph and ovarian homogenates of control crabs during avitellogenic phase did not display any polypeptide subunits corresponding to the yolk proteins: $\mathrm{Vg}$ and $\mathrm{Vn}$. On the other hand, SDS-PAGE analysis of the hemolymph and ovary of MF injected crabs revealed two $\mathrm{Vg}$ subunits with molecular weights 105.96 and $148.31 \mathrm{kDa}$ and two $\mathrm{Vn}$ subunits with molecular weights 97.96 and $141.56 \mathrm{kDa}$. Of the $\mathrm{Vg}$ subunits, the $148.31 \mathrm{kDa}$ band stained intensely and appeared as the major subunit and the $105.96 \mathrm{kDa}$ band which stained mildly with Coomassie Blue was identified as the minor band. The heavily stained $141.56 \mathrm{kDa} \mathrm{Vn}$ band was considered as the major band and the faintly stained 97.96 $\mathrm{kDa}$ as the minor band. On the other hand, only one subunit each was detected for $\mathrm{Vg}$ (148.31 kDa as major band) and $\mathrm{Vn}(112.91 \mathrm{kDa}$ as minor band) in the electropherograms of 20E injected crabs (Figure 1A).

No polypeptide subunits corresponding to the yolk proteins were perceived in the electropherograms of control crabs in previtellogenic phase. Two moderately stained subunits representing $\mathrm{Vg}$ (148.31 as major band and $105.96 \mathrm{kDa}$ as minor band) and two representing $\mathrm{Vn}$ (97.96 as $\mathrm{mi}^{-}$ nor and $141.56 \mathrm{kDa}$ as major band) were apparent in the hemolymph of MF treated crabs during the early previtellogenic phase (June-July). Both the Vg subunits appeared deeply stained by late previtellogenic phase (August-September). The electrophoretic profile of MF injected ovary during late previtellogenic phase has shown three $\mathrm{Vn}$ subunits (the $97.96 \mathrm{kDa}$ as minor band and 112.91 and $141.56 \mathrm{kDa}$ as major bands) (Figures $1 \mathrm{~B}-\mathrm{C}$ ).

Vitellogenin protein extracted from hemolymph of $20 \mathrm{E}$ injected crabs during the early previtellogenic phase was resolved into two moderately stained polypeptide subunits with molecular weights 105.96 (minor band) and 148.31 $\mathrm{kDa}$ (major band). Both the subunits became intensely 
stained major bands in the late previtellogenic phase. The two Vn subunits presented in the ovarian extracts of $20 \mathrm{E}$ injected crabs during early previtellogenic phase were the 97.96 (minor band) and the $141.56 \mathrm{kDa}$ subunits (major band) whereas the polypeptide fractions noticed in the late previtellogenic phase were the 112.91 and $141.56 \mathrm{kDa}$ bands, of which the latter was lightly stained and the former heavily stained during August. Both the bands were perceptible as intensely stained major bands during September (Figures 1B-C).
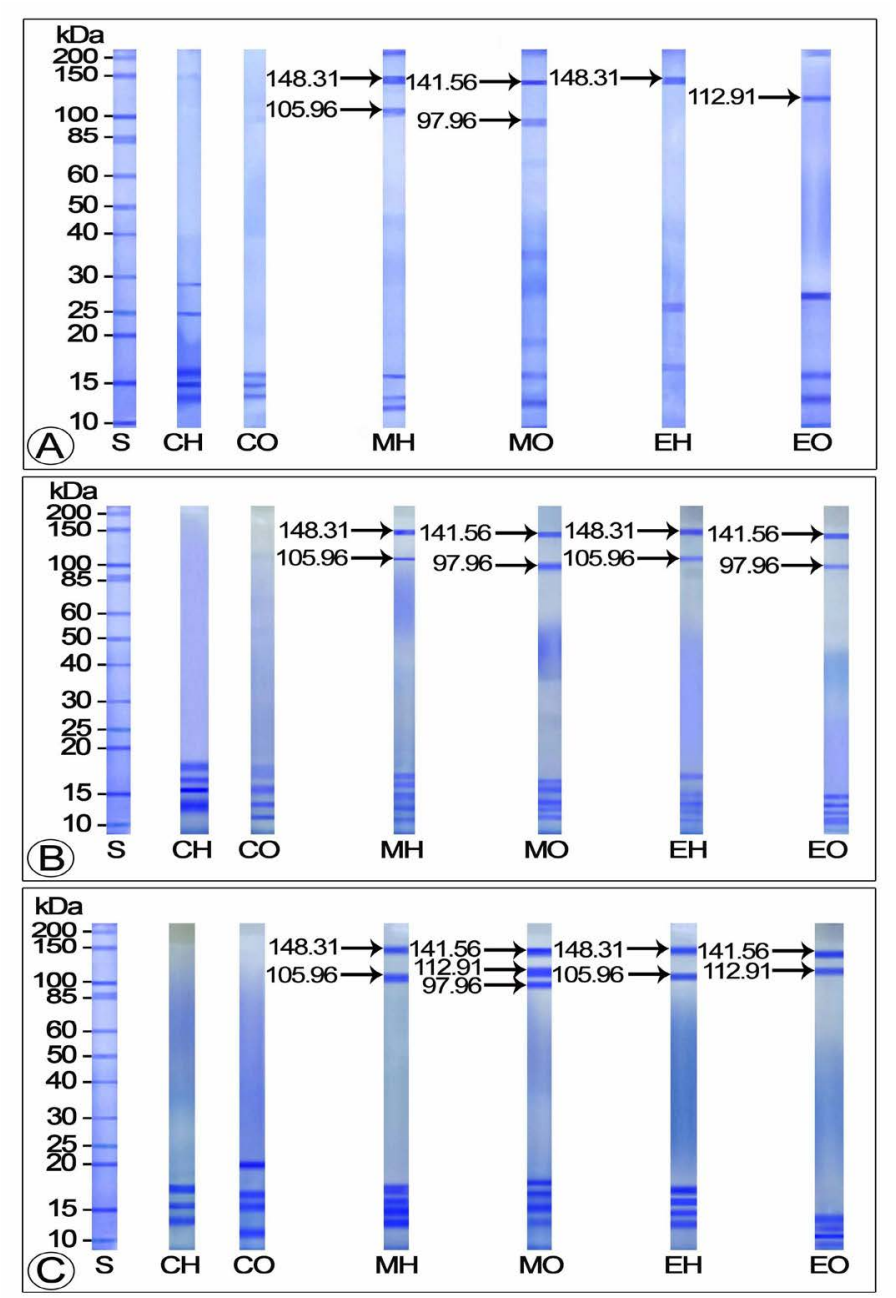

Figure 1: Electropherogram of yolk proteins in hemolymph and ovary of control and experimentals during avitellogenic and previtellogenic phases

(A) Avitellogenic phase (April) (B) Early previtellogenic phase (June) (C) Late previtellogenic phase (September)

$\mathrm{CH}$ : Hemolymph of control crabs; CO: Ovary of control crabs; EH: Hemolymph of 20E injected crabs; EO: Ovary of 20E injected crabs; MH: Hemolymph of MF injected crabs; MO: Ovary of 20E injected crabs; S: Standard marker protein

Effect of MF And 20E Administration on Yolk Protein Production during Vitellogenic Phase The hemolymph samples of control and 20E injected crabs exhibited three $\mathrm{Vg}$ subunits each $(105.96,148.31$ and
$169.37 \mathrm{kDa}$ ) during the early vitelogenic stage. In both control and 20E injected crabs, these subunits were observed as deeply stained major bands, however, in $20 \mathrm{E}$ injected crabs, the $148.31 \mathrm{kDa}$ subunit seemed to be thicker than the other two $(105.96$ and $169.37 \mathrm{kDa})$. Compared to the control and $20 \mathrm{E}$ injected groups, four $\mathrm{Vg}$ subunits were identified in MF injected crabs (97.96, 105.96, 148.31 and $169.37 \mathrm{kDa}$ ), of which the three intensely stained (except the $97.96 \mathrm{kDa}$ minor band) bands were considered as the major subunits. Two Vn subunits each (112.91 and $141.56 \mathrm{kDa}$ ) were displayed in the electropherograms of ovarian extracts from control and $20 \mathrm{E}$ injected crabs during this stage. In $20 \mathrm{E}$ treated crabs, these bands were detected as heavily stained major bands whereas in controls, they remained as mildly stained minor bands. Three intensely stained polypeptide fractions with apparent molecular masses $97.96,112.91$ and $141.56 \mathrm{kDa}$ were noticed in the ovarian extracts of MF injected groups, of which the 97.96 (minor band) and $141.56 \mathrm{kDa}$ (major band) subunits stained intensely while the $112.91 \mathrm{kDa}$ subunit (major band) stained faintly (Figure 2A).

On SDS-PAGE, the hemolymph extract of control, 20E and $\mathrm{MF}$ injected crabs in middle vitellogenic stage presented three $\mathrm{Vg}$ polypeptide subunits each having molecular masses 105.96, 148.31 and $169.37 \mathrm{kDa}$. In control crabs, all the subunits were spotted as moderately stained thin bands while they appeared thick and deeply stained in $\mathrm{MF}$ and $20 \mathrm{E}$ injected females. Four Vn subunits each (97.96, 112.91 and 141.56 and $200 \mathrm{kDa}$ ) were released from the ovarian extracts of control and $20 \mathrm{E}$ injected crabs during this stage. All the subunits in controls and 20E treated crabs stained intensely, nevertheless, the 112.91 and $141.56 \mathrm{kDa}$ bands of $20 \mathrm{E}$ injected crabs appeared thicker than those of the controls. Electrophoretic analysis of ovary from MF injected crabs demonstrated five heavily stained Vn bands (71.41, 97.96, 112.91 and 141.56 and $200 \mathrm{kDa})$, of which three $(97.96,112.91$ and $141.56 \mathrm{kDa})$ appeared as main bands and the remaining two (71.41 and $200 \mathrm{kDa}$ ) as minor bands (Figure 2B).

The electrophoretic profile of the hemolymph and ovarian extracts of controls and experimentals during the late vitellogenic stage unveiled three $\mathrm{Vg}$ polypeptide fractions $(105.96,148.31$ and $169.37 \mathrm{kDa})$ which were moderately stained in control and 20E injected groups and intensely stained in MF injected group. Of the four deeply stained Vn subunits $(71.41,97.96,112.91$ and $141.56 \mathrm{kDa})$ apparent in the ovary of control and $20 \mathrm{E}$ injected crabs, the 112.91 and $141.56 \mathrm{kDa}$ subunits observed as major bands and the 71.41 and $97.96 \mathrm{kDa}$ subunits as minor bands. On the other hand, the $\mathrm{Vn}$ protein of MF injected crabs was composed of heavily stained five subunits with molecular masses 71.41, 97.96, 112.91, 141.56 and $181.71 \mathrm{kDa}$; among which, three subunits $(71.41,112.91$ and 141.56 
$\mathrm{kDa}$ ) appeared as main bands and the remaining two (97.96 and $181.71 \mathrm{kDa}$ ) were minor bands (Figure 2C).

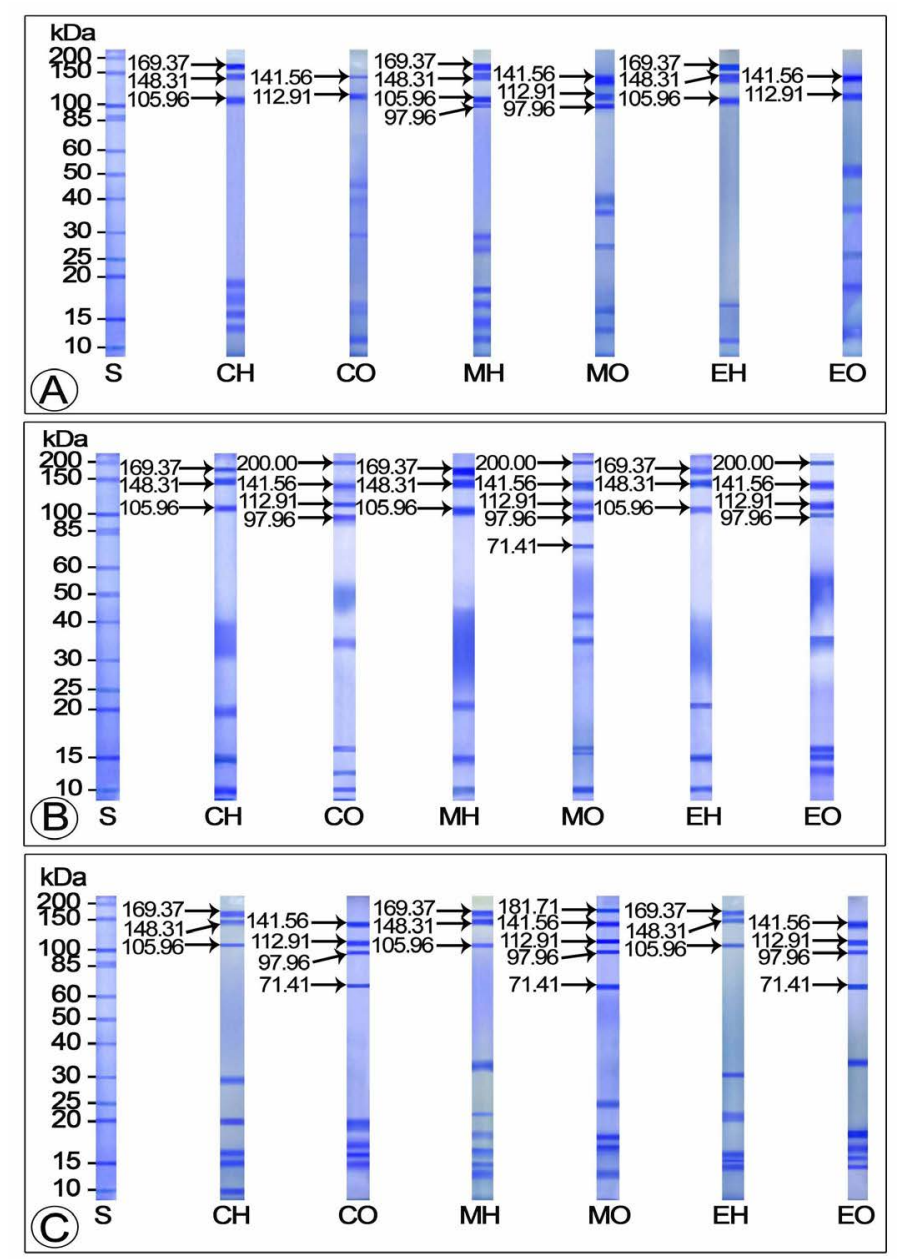

Figure 2: SDS-PAGE separation of yolk proteins of hemolymph and ovary of control and experimentals during vitellogenic phase

(A) Early vitellogenic stage (October) (B) Middle vitellogenic stage (January) (C) Tertiary vitellogenic stage (March)

$\mathrm{CH}$ : Hemolymph of control crabs; CO: Ovary of control crabs; EH: Hemolymph of 20E injected crabs; EO: Ovary of 20E injected crabs; $\mathrm{MH}$ : Hemolymph of MF injected crabs; MO: Ovary of 20E injected crabs; S: Standard protein marker

\section{DISCUSSION}

This study evaluated the effects of exogenous administration of $\mathrm{MF}$ and $20 \mathrm{E}$ on yolk protein profiles in the hemolymph and ovary during various stages of the ovarian cycle in the edible freshwater crab T. schirnerae. Our observations revealed that both $\mathrm{MF}$ and $20 \mathrm{E}$ administration not only induced the production of yolk proteins during the avitellogenic and previtellogenic phases but also increased their production during the vitellogenic phase. ypeptide subunits having molecular masses 97.96, 105.96, 148.31 and $169.37 \mathrm{kDa}$ in the hemolymph of T. schirnerae. In crustaceans, the number and molecular masses of subunits constituting the yolk protein $\mathrm{Vg}$ varied with species (Tsukimura, 2001; Auttarat et al., 2006). For example, the $\mathrm{Vg}$ of the Chinese mitten crab Eriocheir sinensis (Chen et al., 2004) and blue crab Callinectes sapidus (Zmora et al., 2007) was made up of two subunits with dissimilar masses. Three polypeptide subunits were identified in the $\mathrm{Vg}$ of Potamon potamios (Pateraki and Stratakis, 1997), P. pelagicus (Ravi and Manisseri, 2011) and the freshwater prawn M. malcolmsonii (Shanju and Geraldine, 2010). Zacharia and Kakati (2004) described the occurrence of six Vg subunits in P. merguiensis.

In crustaceans, the number of $\mathrm{Vn}$ subunits in the ovary varied from 2-8 (Quinitio et al., 1990; Vafopoulou and Steel, 1995). The electrophoretic analysis of the ovary of control and experimental T. schirnerae revealed six Vn polypeptide subunits with molecular weights 71.41 , 97.96, $112.91,141.56,181.71$ and $200 \mathrm{kDa}$. In contrast to our observations, two fractions were reported in Charybdis feriatus (Komatsu and Ando, 1992a), E. japonicus (Komatsu and Ando, 1992a) and M. malcolmsonii (Shanju and Geraldine, 2010); three in Sicyonia ingentis (Tsukimura et al., 2000); four in M. rosenbergii (Komatsu and Ando, 1992a), C. sapidus (Lee and Watson, 1995) and P. potamios (Pateraki and Stratakis, 2000), five in Procambarus clarkii (Lui and O'Connor, 1976) and P. chinensis (Chang et al., 1996) and eight in P. monodon (Chang et al., 1993). From the above observations including the current one, it is concluded that species specific differences occur in the number and molecular weights of polypeptide subunits constituting the yolk protein $\mathrm{Vn}$.

From the results, it was clear that in T. schirnerae, vitellogenic stage specific variations occur in the number and molecular masses of subunits constituting Vg and Vn. Comparable situations were reported in P. semisulcatus, where the $\mathrm{Vg}$ encompassed two subunits with molecular masses 74 and $199 \mathrm{kDa}$ and $\mathrm{Vn}$ consisted of four subunits with molecular masses 72, 79, 100 and $207 \mathrm{kDa}$ (Avarre et al., 2003). In C. sapidus, two subunits with molecular weights 78.5 and $207.3 \mathrm{kDa}$ (Zmora et al., 2007) were identified in the hemolymph and four with molecular weights 86,109 , 168 and $188 \mathrm{kDa}$ in the ovary (Lee and Watson, 1995). In contrast, identical polypeptide fractions were apparent in the $\mathrm{Vg}(89,100$ and $170 \mathrm{kDa})$ and $\mathrm{Vn}(89$ and $100 \mathrm{kDa})$ of M. malcolmsonii (Shanju and Geraldine, 2010). A similar trend was observed in the hemolymph and ovary of $M$. rosenbergii $(90,102$ and $199 \mathrm{kDa}$ ) (Wilder et al., 1994) and P. potamios (85, 105 and $115 \mathrm{kDa}$ ) (Pateraki and Stratakis, 1997; 2000).

The current study confirmed the presence of four $\mathrm{Vg}$ polDecember 2020 | Volume 8 | Issue 2 | Page 59

Our observations revealed that MF administration in- 
duced the production of yolk proteins during the avitellogenic and previtellogenic phases as demonstrated by the presence of $\mathrm{Vg}$ and $\mathrm{Vn}$ bands in the electropherograms of the experimentals over the controls. Similar results were obtained in Oziothelphusa senex senex, wherein significant increase in ovarian $\mathrm{Vg}$ level was discerned with MF injection during the immature stage (Reddy and Reddy, 2015). The ovarian $\mathrm{Vg}$ level was significantly high in $M$. rosenbergii treated with MF during the previtellogenic phase (Hemalatha et al., 2016). In T. schirnerae, the electropherograms of MF injected crabs during the vitellogenic phase exhibited more number of $\mathrm{Vg}$ and $\mathrm{Vn}$ subunits with increased staining intensity and thickness compared to the $20 \mathrm{E}$ injected and control crabs. In agreement with our findings, in $P$. clarkii, MF administration induced the production of yolk proteins in the ovary during vitellogenesis (Rodriguez et al., 2002). Studies of Mak et al. (2005) with farnesoic acid in the red crab C. feriatus have shown that Vg gene expression was negligible in the non-reproductive phase, reached its maximum through middle vitellogenesis and dropped to minimum in late vitellogenesis. In $C$. quadricarinatus, it was reported that significant accumulation of $\mathrm{Vg}$ was perceptible in ovaries treated with MF during early pre-reproductive period and not during the reproductive period (Medesani et al., 2012). In contrast, in Neobelice granulata, MF administration boosted the $\mathrm{Vg}$ and $\mathrm{Vn}$ levels in the hemolymph and ovary only during the post-reproductive period (Medesani et al., 2015).

From the above observations including the present one, it is very clear that MF has an important role in the synthesis, release and transportation of $\mathrm{Vg}$ into the ovary. One possible explanation for the appearance of $\mathrm{Vg}$ and $\mathrm{Vn}$ proteins in the hemolymph and ovary of avitellogenic and previtellogenic ovaries is that the exogenously administered $\mathrm{MF}$ might have triggered the production of $\mathrm{Vg}$ in the hepatopancreas, its discharge to the hemolymph and storage by the ovary. The reason for the manifestation of increased number of $\mathrm{Vg}$ and $\mathrm{Vn}$ subunits with increased staining intensity and thickness in MF injected females compared to the $20 \mathrm{E}$ injected and control crabs during the vitellogenic phase is that the exogenously administered MF enhanced $\mathrm{Vg}$ uptake and its conversion to $\mathrm{Vn}$ by the ovary during the vitellogenic phase.

However, there were occasions when MF administration had no effect on $\mathrm{Vg}$ or $\mathrm{Vn}$ production. For instance, no positive correlation was found between the hemolymph $\mathrm{Vg}$ titer and MF administration in senescent females of Homarus americanus (Tsukimura et al., 1993) and Triops longicaudatus (Riley and Tsukimura, 1998) and S. ingentis (Balasubramanian et al., 2010).

In T. schirnerae, $20 \mathrm{E}$ treatment induced the production of $\mathrm{Vg}$ and $\mathrm{Vn}$ during the avitellogenic and previtellogenic phases as evinced from the presence of $\mathrm{Vg}$ and $\mathrm{Vn}$ bands in the electropherograms of experimentals over the controls. In support of this, in the same species, the same authors proved histologically that $20 \mathrm{E}$ injection induced the avitellogenic and previtellogenic ovaries to grow into vitellogenic ovaries (Sudha Devi and Aswani, 2019). In P. vannamei, Chan (1995) witnessed the accumulation of ovarian polypeptides with increase in ovarian ecdysteroid levels during secondary vitellogenesis. The parallelism between hemolymph Vg concentration and ecdysteroid titer during vitellogenesis was reported in isopods, amphipods and crabs, signifying their role in Vg synthesis (Shih, 1997; Steel and Vafopoulou, 1998; Zapata et al., 2003). Mc Carthy (1980) and Kanazawa and Teshima (1971) described the possible involvement of ecdysteroids in exhilarating $\mathrm{Vg}$ synthesis and release into the hemolymph and or its uptake by the ovary.

Conversely, in vitro administration of $20 \mathrm{E}$ did not induce Vg synthesis in stage I ovary of P. vannamei (Chan, 1995). In Carcinus maenas, the process of vitellogenesis was continued even after Y-organectomy (Demeusy, 1962). In $M$. rosenbergii, Okumura and Aida (2000) did not find any involvement of ecdysteroids in ovarian development.

The mode of operation of $\mathrm{MF}$ and 20E in the control of $\mathrm{Vg}$ and $\mathrm{Vn}$ production is still unclear. MF may act directly by triggering the production of $\mathrm{Vg}$ in the hepatopancreas or augments the release of $\mathrm{Vg}$ into the hemolymph and incorporation by the ovary or indirectly via the VSH that promotes the hepatopancreas to synthesize and secrete $\mathrm{Vg}$ into the hemolymph and its assimilation by the ovary. In decapod crustaceans ecdysteroids may act directly via receptor (EcR) facilitated transport of Vg into the ovary with ecdysteroids in their oocytes (Warrier and Subramoniam, 2002) or indirectly via the VSOH for the synthesis of $\mathrm{Vg}$ in the hepatopancreas and its uptake by the ovary (Kanazawa and Teshima, 1971, Yano and Chinzei, 1987). The presence of ecdysteroids possibly stimulate the ecdysone responsive element in the upstream of the $\mathrm{Vg}$ gene which in turn initiate the transcription of $\mathrm{Vg}$ gene (Tokishita et al., 2006). In O. senex senex, Girish et al. (2015) described increased EcR expression in the hepatopancreas and activation of ecdysteroid responsive gene during vitellogenesis stage I and II.

To conclude, this study proved that exogenous administration of $\mathrm{MF}$ and $20 \mathrm{E}$ in T. schirnerae induced the production of $\mathrm{Vg}$ and $\mathrm{Vn}$ during the avitellogenic and previtellogenic phases. The electropherograms of MF and 20E injected crabs during the vitellogenic phase displayed more number of $\mathrm{Vg}$ and $\mathrm{Vn}$ bands with increased staining intensity and thickness compared to the control crabs. Though both $\mathrm{MF}$ and $20 \mathrm{E}$ were able to stimulate the production of $\mathrm{Vg}$ and Vn during the avitellogenic and previtellogenic phases, 
the effects were far more pronounced in $\mathrm{MF}$ injected crabs than 20E injected ones. Further molecular studies pertaining to the receptor activities of $\mathrm{Vg}$ and $\mathrm{Vn}$ are needed to solve this problem.

\section{ACKNOWLEDGEMENTS}

The financial support provided by the Kerala State Council for Science Technology \& Environment (Order No. P 115/2016/KSCSTE, dated 03-05-2016) in carrying out this research is gratefully acknowledged.

\section{CONFLICT OF INTEREST}

The authors declare that they have no conflict of interest related to the work.

\section{AUTHORS CONTRIBUTION}

All authors contributed eqaully.

\section{REFERENCES}

- Abdu U, Takac P, Laufer H, Sagi A (1998). Effect of methyl farnesoate on late larval development and metamorphosis in the prawn Macrobrachium rosenbergii Decapoda, Palaemonidae: a juvenoid-like effect? Biol. Bull. 195: 112119. https://doi.org/10.2307/1542818.

- Auttarat J, Phiriyangkul P, Utarabhand P (2006). Characterization of vitellin from the ovaries of the banana shrimp litopenaeus merguiensis. Comp. Biochem. Physiol. B. 143: 27-36. https://doi.org/10.1016/j.cbpb.2005.09.009

- Avarre JC,Michelis R, Tietz A,Lubzens E (2003). Relationship between vitellogenin and vitellin in a marine shrimp (Penaeus semisulcatus) and molecular characterization of vitellogenin complimentary DNAs. Biol. Reprod. 69: 355364. https://doi.org/10.1095/biolreprod.102.011627

- Balasubramanian CP, Fierro IJ, Tsukimura B (2010). Stimulation of ovarian growth by methyl farnesoate and eyestalk ablation in penaeoidean model shrimp, Sicyonia ingentis Burkenroad, (1938). Aqua. Res. 41(12): 1887-1897. https://doi.org/10.1111/j.1365-2109.2010.02612.x

- Blanchet-Tournier MF (1982). Quelques aspects des interactions hormonales entre la mue et la vitellogenèse chez le Crustacé Amphipode Orchestia gammarellus (Pallas). Reprod. Nutr. Develop. 22(2): 325-344. https:// doi.org/10.1051/rnd:19820304

- Chaix JC, De Reggi M (1982). Ecdysteroid levels during ovarian development and embryogenesis in the spider crab Acanthonyx lunulatus. Gen. Comp. Endocrinol. 47(1): 7-14. https://doi.org/10.1016/0016-6480(82)90076-4

- Chan SM (1995). Possible roles of 20-hydroxyecdysone in the control of ovary maturation in the white shrimp Penaeus vannamei (Crustacea: Decapoda). Comp. Biochem. Physiol. C. 112(1): 51-59. https://doi.org/10.1016/07428413(95)00073-9

- Chang CF, Lee FY, Huang YS (1993). Purification and characterization of vitellin from the mature ovaries of prawn, Penaeus monodon. Comp. Biochem. Physiol. B. 105: 409-414. https://doi.org/10.1016/0305-0491(93)90249-5

- Chang CF, Jeng SR, Lin MN, Tin YY (1996). Purification and characterization of vitellin from the mature ovaries of prawn, Penaeus chinensis. Invertebr. Reprod. Dev. 29: 87-93. https://doi.org/10.1080/07924259.1996.9672500

- Chang E, Chang S, Mulder E (2001). Hormones in the lives of crustaceans: an overview. Am. Zool. 41: 1090-1097.https:// doi.org/10.1668/0003-1569(2001)041[1090:HITLOC]2. $0 . \mathrm{CO} ; 2$

- Charmantier G, Charmantier-Daures M, Van Herp F (1997). Hormonal regulation of growth and reproduction in crustaceans. In: Recent advances in marine biotechnology, Fingerman M, Nagabhushanam R, Thompson MF. (Eds.), Oxford and IBH Publishing, New Delhi, Volume I: $109-161$.

- Charniaux-Cotton H (1985). Vitellogenesis and its control in malacostracan Crustacea. Am. Zool. 25: 197-206. https:// doi.org/10.1093/icb/25.1.197

- Chen L, Jiang H, Zhou Z, Li K, Deng GY, Liu Z (2004). Purification of vitellin from the ovary of Chinese mitten handed crab (Eriocheir sinensis) and development of an antivitellin ELISA. Comp. Biochem. Physiol. B. 138: 305311. https://doi.org/10.1016/j.cbpc.2004.04.012

- Demeusy N (1962). Role de la gland de mue dans l'evolution ovarianne du crabe Carcinus maenas Linn. Can. Biol. Mar. 3: $37-56$

- Girish BP, Swetha CH, Reddy PS (2015). Induction of ecdysteroidogenesis, methyl farnesoate synthesis and expression of ecdysteroid receptor and retinoid $\mathrm{X}$ receptor in the hepatopancreas and ovary of the giant mud crab, Scylla serrata by melatonin. Gen. Comp. Endocrinol. 217218: 37-42. https://doi.org/10.1016/j.ygcen.2015.05.007.

- Gunamalai V, Kirubagaran R, Subramoniam T (2004). Hormonal coordination of moulting and female reproduction by ecdysteroids in the mole crab Emerita asiatica (Milne Edwards). Gen. Comp. Endocrinol. 138: 128-138. https://doi.org/10.1016/j.ygcen.2004.06.002

- Hemalatha M, Parameswari K, Kishori B, Reddy BS, Reddy PR (2016). Methyl farnesoate induced ovarian maturation in freshwater prawn, Macrobrachium rosenbergii. J. Oceanogr. Mar. Res. 4(1): 1-6. https://doi.org/10.4172/25723103.1000142

- Kanazawa A, Teshima SI (1971). In vivo conversion of cholesterol to steroid hormones in the spiny lobster, Panulirus japonicus. Bull. Jpn. Soc. Fish. 37: 891-898. https://doi.org/10.2331/suisan.37.891

- Komatsu M, Ando S (1992a). Isolation of crustacean egg yolk lipoproteins by differential density gradient ultracentrifugation. Comp. Biochem. Physiol. B. 103: 363368. https://doi.org/10.1016/0305-0491(92)90305-B

- Laemmli UK (1970). Cleavage of structural proteins during the assembly of the head of bacteriophage T4. Nature 227: 680-685. https://doi.org/10.1038/227680a0

- Lee CY, Watson RD (1995). In vitro study of vitellogenesis in the blue crab (Callinectes sapidus): site and control of vitellin synthesis. J. Exp. Zool. 271: 364-372. https://doi. org/10.1002/jez.1402710506

- Lui CW, O'Connor JD (1976). Biosynthesis of lipovitellin by the crustacean ovary. II. Characterization of and in vitro incorporation of amino acids into the purified subunits. J. Exp. Zool. 195: 41-52. https://doi.org/10.1002/ jez.1401950105. 
- Mak AS, Choi CL, Tiu SH, Hui JH, He JG, Tobe SS, Chan SM (2005). Vitellogenesis in the red crab Charybdis feriatus: hepatopancreas-specific expression and farnesoic acid stimulation of vitellogenin gene expression. Mol. Reprod. Dev. 70: 288-300. https://doi.org/10.1002/mrd.20213.

- Mc Carthy JF (1980). Ecdysone metabolism and the interruption in the land crab, Gecarcinus lateralis. Biol. Bull. 158: 91-102. https://doi.org/10.1016/00121606(77)90300-1

- Medesani DA, Ferre LE, Grodzielski M, Rodriguez EM (2012). In vitro effect of methyl farnesoate on the vitellogenin content of ovary and hepatopancreas, in the crayfish Cherax quadricarinatus. Invertebr. Reprod. Dev. 56(2): 138-143. https://doi.org/10.1080/07924259.2011.5 82691

- Medesani DA, Ferre LE, Canosa IS, Silveyra GR, Rodriguez EM (2015). Induction of vitellogenesis by 17-hydroxyprogesterone and methyl farnesoate during post-reproductive period, in the estuarine crab Neohelice granulata. Invertebr. Reprod. Dev. 59(2): 104-110. http:// doi.org/10.1080/07924259.2015.1019014

- Meusy JJ, Payen GG (1988). Female reproduction in malacostracan Crustacea. Zool. Sci. 5: 217-265.

- Meusy JJ (1980). Vitellogenin, the extraovarian precursor of the protein yolk in Crustacea: A review. Reprod. Nutr. Develop. 20(1A): 1-21. https://doi.org/10.1051/ rnd:19800101.

- Muhd-Farouk H, Nurul HA, Abol-Munafi AB, Mardhiyyah MP, Hasyima-Ismail N, Manan H, Fatihah SN, AminSafwan A, Ikhwanuddin M (2019). Development of ovarian maturation in orange mud crab, Scylla olivacea (Herbst, 1976) through induction of eyestalk ablation and methyl farnesoate. Arab J. Basic. Appl. Sci. 26(1): 171-181. https:// doi.org/10.1080/25765299.2019.1588197

- Nagaraju GPC, Ramamurthi R, Reddy PS (2002). Methyl farnesoate stimulates ovarian growth in Penaeus indicus. In: Recent trends in biotechnology, Harikumar VS. (Ed.), Agrobios, India, 85-89. https://doi.org/10.4172/25723103.1000142

- Nagaraju GPC, Suraj N, Reddy PS (2003). Methyl farnesoate stimulates gonad development in Macrobrachium malcolmsonii (H. Milne Edwards) (Decapoda, Palaemonidae). Crustaceana 76: 1171-1178. https://doi. org/10.1163/156854003773123401.

- Okumura T, Aida K (2000). Fluctuations in hemolymph ecdysteroid levels during the reproductive and nonreproductive moult cycles in the giant freshwater prawn Macrobrachium rosenbergii. Fish. Sci. 66(5): 876-883. https://doi.org/10.1046/j.1444-2906.2000.00142.x

- Otsu T (1963). Bihormonal control of sexual cycle in the freshwater crab Potamon dehaani. Embryologia 8: 1-20. https://doi.org/10.1111/j.1440-169X.1963.tb00183.x

- Pateraki LE,Stratakis E(1997).Characterization of vitellogenin and vitellin from land crab Potamon potamios: identification of a precursor polypeptide in the molecule. J. Exp. Zool. 279: 597-608. https://doi.org/10.1002/(SICI)1097010X(19971215)279:6<597::AID-JEZ8>3.0.CO;2-I

- Pateraki LE, Stratakis E (2000). Synthesis and organization of vitellogenin and vitellin molecules from the land crab Potamon potamios. Comp. Biochem. Physiol. B. 125: 53-61. https://doi.org/10.1016/S0305-0491(99)00160-1

- Picaud JL, Souty C (1980). Demonstration par immunoautoradiographie de la synthese de la vitellogenine par le tissu adipeux de Porcellio dilatatus Brandt (Crustace, isopode). C. R. Acad. Sci. D. 290: 1019-1021.

- Quinitio ET, Hara A, Yamaguchi K, Fuji A (1990). Isolation and characterization of vitellin from the ovary of Penaeus monodon. Invertebr. Reprod. Dev. 17: 221-227. https://doi. org/10.1080/07924259.1990.9672114

- Ravi R, Manisseri MK (2011). Characterization of yolk proteins in Portunus pelagicus (Linnaeus 1758). Fish. Technol. 48: 99-103.

- Reddy BS, Reddy PR (2015). Methyl farnesoate induced ovarian vitellogenin synthesis in freshwater rice field crab Oziothelphusa senex senex Fabricus. J. Infertil. Reprod. Biol. 3: 237-244.

- Reddy PR, Nagaraju GPC, Reddy PS (2004). Involvement of methyl farnesoate in the regulation of moulting and reproduction in the freshwater crab Oziotelphusa senex senex. J. Crust. Biol. 24(3): 511-515. https://doi. org/10.1651/C-2478

- Riley HG, Tsukimura B (1998). Yolk protein synthesis in rice land tadpole shrimp, Triops longicaudatus, measured by in vitro incorporation of H3-leucine. J. Exp. Zool. 281: 238-247. https://doi.org/10.1002/(SICI)1097010X(19980615)281:3<238::AID-JEZ10>3.0.CO;2-7

- Rodriguez EM, Greco LSL, Medesani DA, Laufer H, Fingerman M (2002). Effect of methyl farnesoate, alone and in combination with other hormones, on ovarian growth of the red swamp crayfish, Procambarus clarkii, during vitellogenesis. Gen. Comp. Endocrinol. 125(1): 3440. https://doi.org/10.1006/gcen.2001.7724

- Shanju S, Geraldine P (2010). Biochemical characterization of vitellin from the freshwater prawn Macrobrachium malcolmsonii. Invertebr. Reprod. Dev. 54: 41-52. https://doi. org/10.1080/07924259.2010.9652315

- Shih JT (1997). Sex steroid-like substances in the ovaries, hepatopancreas and body fluid of female, Mictyris brevidactylus. Zool. Stud. 36: 136-145.

- Souty C, Besse G, Picaud JL (1982). Ecdysone stimulates the rate of vitellogenin release in hemolymph of the terrestrial crustacean Isopoda Porcellio dilatatus Brandt. C. R. Acad. Sci. D. 294: 1057-1060.

- Steel CGH, Vafopoulou X (1998). Ecdysteroid titres in hemolymph and other tissues during moulting and reproduction in the terrestrial isopod, Oniscus asellus (L.). Invertebr. Reprod. Dev. 34(2-3): 187-194. https://doi. org/10.1080/07924259.1998.9652652

- Subramoniam T (2000). Crustacean ecdysteroids in reproduction and embryogenesis. Comp. Biochem. Physiol. C. 125: 135-156. https://doi.org/10.1016/S07428413(99)00098-5

- Subramoniam T (2017). Steroidal control of vitellogenesis in Crustacea: a new understanding for improving shrimp hatchery production. Proc. Indian Natl. Sci. Acad. 83(3): 595-610. https://doi.org/10.16943/ptinsa/2017/48969

- Sudha Devi AR, Aswani A (2018). Effect of methyl farnesoate administration on ovarian growth and maturation in the freshwater crab Travancoriana schirnerae. Egypt. J. Aquat. Biol. Fish. 22(5): 257-271. https://doi.org/10.21608/ EJABF.2019.24189

- Sudha Devi AR, Aswani A (2019). Effect of ecdysteroids on oogenesis in the freshwater crab Travancoriana schirnerae Bott, 1969 (Crustacea-Gecarcinucidae). Braz. J. Biol. Sci. 6: 87-101. https://doi.org/10.21472/bjbs.061208

- Tiu S,Hui J,Mak A, He J, Chan S (2006). Equal contribution of 
hepatopancreas and ovary to the production of vitellogenin (PmVg1) transcripts in the tiger shrimp, Penaeus monodon. Aquaculture 254: 666-674. https://doi.org/10.1016/j. aquaculture.2005.11.001

- Tokishita SI, Kato Y, Kobayashi T, Nakamura S, Ohta T, Yamagata $H$ (2006). Organization and repression by juvenile hormone of a vitellogenin gene cluster in the crustacean, Daphnia magna. Biochem. Biophys. Res. Commun. 345: 362-70.

- Tsukimura B (2001). Crustacean vitellogenesis: its role in oocyte development. Am. Zool. 41(3): 465-476. https:// doi.org/10.1093/icb/41.3.465

- Tsukimura B, Bender JS, Linder CJ (2000). Developmental aspects of gonadal regulation in the ridgeback shrimp, Sicyonia ingentis. Comp. Biochem. Physiol. A. 127: 215-224.

- Tsukimura B, Kamemoto FI, Borst DW (1993). Cyclic nucleotide regulation of methyl farnesoate synthesis by the mandibular organ of the lobster, Homarus americanus. J. Exp. Zool. 265: 427-31. https://doi.org/10.1002/ jez.1402650412

- Vafopoulou X, Steel CGH (1995). Vitellogenesis in the terrestrial isopod, Oniscus asellus (L): Characterization of vitellin and vitellogenesis and changes in their synthesis throughout the intermoult cycle. Invertebr. Reprod. Dev. 28: 87-95. https://doi.org/10.1080/07924259.1995.96724 69

- Van Herp F, Soyez D (1997). Arthropoda-Crustacea. In: Progress in reproductive endocrinology, Vol. VIII. Reproductive biology of invertebrates, Adiyodi KG, Adiyodi RG. (Eds.), Wiley, New York, Volume 8: 247-275.

- Vogel J, Borst DW (1989). Spider crab yolk protein: molecular characterization and the effects of methyl farnesoate (MF) on its hemolymph levels. Am. Zool. 29: 49A.
- Warrier S, Subramoniam T (2002). Receptor mediated yolk protein uptake in the crab Scylla serrata: crustacean vitellogenin receptor recognizes related mammalian serum lipoproteins. Mol. Reprod. Dev. 61: 536-548. https://doi. org/10.1002/mrd.10106

- Wilder MN, Okumura T, Suzuki Y, Fusetani N, Aida K (1994). Vitellogenin production induced by eyestalk ablation in juvenile giant freshwater prawn Macrobrachium rosenbergii and trial methyl farnesoate administration. Zool. Sci. 11(1): 45-53.

- Yano I, Chinzei Y (1987). Ovary is the site of vitellogenin synthesis in kuruma prawn, Penaeus japonicas. Comp. Biochem. Physiol. B. 86(2): 213-218. https://doi. org/10.1016/0305-0491(87)90280-X

- Zacharia S, Kakati VS (2004). Characterization of vitellogenin and vitellin of Fenneropenaeus merguiensis (De Man). Indian J. Fish. 51: 255-263.

- Zapata V, Greco LL, Medesani D, Rodriguez EM (2003). Ovarian growth in the crab Chasmagnathus granulata induced by hormones and neuroregulators throughout the year. In vivo and in vitro studies. Aquaculture 224(1-4): 339-352. https://doi.org/10.1016/S0044-8486(03)00226-6

- Zerbib C, Meusy JJ (1983). Electron microscopic observations of the subepidermal fatbody changes following ovariectomy in Orchestia gammarellus (Pallas) (Crustacea: Amphipoda). Invertebr. Reprod. Dev. 6: 123-127. https://doi.org/10.108 0/01651269.1983.10510031

- Zmora N, Trant J, Chan SM, Chung JS (2007). Vitellogenin and its messenger mRNA duringovarian development in the female crab, Callinectes sapidus gene expression, synthesis, transport and cleavage. Biol. Reprod. 77: 138-146. https:// doi.org/10.1095/biolreprod.106.055483 